\title{
KAJIAN MODEL DESAIN APLIKASI MOBILE YANG BERKELANJUTAN PADA DESA WISATA
}

\section{STUDY OF SUSTAINABLE MOBILE APPLICATION DESIGN MODELS IN TOURISM VILLAGES}

\section{Muhamad As'adi'), Akhmad Nidhomuz Zaman²), Alina Cynthia Dewi' ${ }^{3)}$, Arraz Naoval Viacenza4), Donny Montreano5)}

1,2,3,4,5) Teknik Industri, Fakultas Teknik, Universitas Pembangunan Nasional Veteran Jakarta, Jalan Limo Raya, 16531 Depok, Indonesia

\begin{tabular}{|c|c|}
\hline ARTICLE INFORMATION & A B S T R A C T \\
\hline $\begin{array}{l}\text { Article history: } \\
\text { Received: April 24, } 2020 \\
\text { Revised: April 29, } 2020 \\
\text { Accepted: May 22, } 2020\end{array}$ & $\begin{array}{l}\text { The } 4.0 \text { industrial revolution created opportunities for MSMEs in rural areas to build } \\
\text { and develop marketing networks on a wide and efficient scale. Applying digitization } \\
\text { in a village will have an impact on the potential of what is not yet known in general. } \\
\text { This study discusses the design of Android applications that are expected to provide } \\
\text { new experiences to visitors to find out the potential of the village that has not been }\end{array}$ \\
\hline $\begin{array}{l}\text { Keywords: } \\
\text { AHP } \\
\text { Design Application } \\
\text { Design comparison } \\
\text { QFD }\end{array}$ & $\begin{array}{l}\text { model that evaluates in two villages with different cultures and potentials, namely } \\
\text { Ponggok Klaten Village and Kadubungbang Pandeglang Village. The results of QFD } \\
\text { and AHP can help applications that are flexible to the village as well as visitor } \\
\text { application needs and application priority features. Of the different features, because } \\
\text { there are indeed differences between villages with different topography. }\end{array}$ \\
\hline
\end{tabular}

\section{A B S T R A K}

Kata kunci:

AHP

Desain aplikasi

Desain perbandingan

QFD
Revolusi industri 4.0 menciptakan peluang bagi UMKM di daerah pedesaan untuk dapat membangun dan mengembangkan jaringan pemasaran pada skala yang luas dan efisien. Penerapan digitalisasi pada suatu Desa akan memberikan dampak luias terhadap potensi apa yang belum diketahui secara umum. Penelitian ini bertujuan untuk mengusulkan desain aplikasi android yang diharapkan dapat memberikan pengalaman baru kepada para pengunjung untuk mengetahui potensi desa yang belum terekspos. Kontribusi dari penelitian ini adalah untuk mempelajari perbandingan pada desain model aplikasi yang dievaluasi pada dua desa dengan budaya dan potensi yang berbeda, yaitu Desa Ponggok Klaten dan Desa Kadubungbang Pandeglang. Hasil QFD dan AHP dapat diketahui bahwa aplikasi bersifat fleksibel terhadap penerapan dua desa serta prioritas kebutuhan pengunjung dan fitur prioritas aplikasi. Hasil erbandingan terdapat kesamaan dalam kebutuhan pelanggan dan perbedaan dalam desain fitur, karena kedua desa memiliki budaya dan topografi yang berbeda.

This is an open access article under the $\underline{\mathrm{CC}-\mathrm{BY}}$ license.

${ }^{*}$ Corresponding Author

Name : Akhmad Nidhomouz Zaman

E-mail: akhmadzaman19@gmail.com

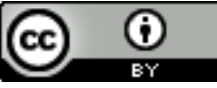

(c) 2020 Some rights reserved

\section{PENDAHULUAN}

Revolusi industri 4.0 merupakan istilah yang relatif baru dan mungkin masih belum banyak dipahami pada bidang industri. Industri 4.0 mengarah pada era digitalisasi. Sistem yang berbasis digitalisasi contoh diantaranya model bisnis, lingkungan, sistem produksi, mesin, operator, produk dan 
layanan. Semuanya saling terhubung di dalam proses digital dengan representasi virtual yang sesuai [1]. Menurut pendapat Menteri Perindustrian (Kabinet Kerja) Airlangga Hartarto, Industri 4.0 menjadikan suatu proses produksi berjalan dengan internet sebagai penopang utama. Semua obyek dilengkapi dengan perangkat teknologi yang dibantu sensor dan mampu berkomunikasi sendiri dengan sistem teknologi informasi [2]. Industri 4.0 secara fundamental membuat berubahnya cara manusia berpikir, hidup, dan berhubungan satu dengan yang lain. Era ini akan mendisrupsi berbagai aktivitas manusia dalam berbagai bidang, tidak hanya dalam bidang teknologi, namun juga bidang yang lain seperti ekonomi dan sosial [3]. Penyelenggara pariwisata diwajibkan memiliki berbagai platform dan saluran yang mampu menjangkau wisatawan dan melakukan komunikasi interaktif. Hal tersebut didorong oleh teknologi yang mengubah kompleksitas persaingan menjadi lebih tinggi. Keunggulan di sektor digital, akan berpotensi menjadikan suatu penyelenggara pariwisata lebih baik daripada pesaingnya. Hal tersebut tentunya menjadi tantangan baru bagi penyelenggara pariwisata tradisional [4]. Teknologi digital menciptakan peluang bagi usaha-usaha kecil UMKM khususnya yang berada di wilayah pedesaan untuk bisa membangun dan mengembangkan jaringan pemasaran dalam skala yang luas, besar dan efisien. Pada suatu Desa terdapat potensi besar untuk bisa menjadi desa yang mandiri serta bisa mensejahterahkan warganya [5]. Penerapan teknologi pada proses bisnis berperan dalam persaingan berinovasi untuk meningkatkan kinerja usaha yang berpengaruh terhadap keuntungan bagi perusahaan [6]. Peningkatan kinerja usaha dapat dilakukan dengan menerapkan teknologi pada bisnis didalam perusahaan untuk menciptakan nilai bagi pelanggan [7].

Beberapa asosiasi dari Jerman bekerja sama dalam pembuatan model referensi untuk Industri 4.0 adalah pengembangan bahasa bersama dan kerangka kerja terstruktur [8] marcon yang menggambarkan dasar-dasar Industri 4.0. Hal ini dimaksudkan untuk membantu implementasi teknologi Industri 4.0 [6]. Inovasi baru [9] adalah pengembangan produk melalui desain model aplikasi android yang berfungsi pada kemudahan mengeksplor dari potensi suatu Desa $X$, desain aplikasi yang dikembangkan terdapat fitur-fitur yang memudahkan pengunjung bisa mengenal suatu desa selain itu produk-produk unggulan hasil desa bisa lebih dikenal masyarakat dengan adanya aplikasi. [10] dan [11] mengemukakan kebutuhan dan penerimaaan pelanggan terhadap model bisnis yang baru diantaranya adalah: faktor harga, desain, keandalan, ramah lingkungan, pelayanan, multifungsi, resiko, fleksibilitas, dan pengetahuan yang lebih dari pihak penyedia jasa. [12] melakukan identifikasi dan penggembangan kebutuhan desain model terhadap mobile phone dengan mengusulkan metode Quality Function Deplotment (QFD) suatu proses yang terstruktur untuk menentukan kebutuhan pelanggan dan menerjemahkan kebutuhan tersebut kedalam respon teknis yang relevan, terkait dengan fungsi utama produk: produk pendukung, tampilan, fungsi tambahan produk, fitur pendukung jasa, ketersediaan fungsi produk, robustness, fleksibilitas produk, input, throughput, output, lingkungan, dan permintaan pelanggan yang diharapkan dapat menyeimbangkan pembangunan ekonomi dan perlindungan lingkungan. Pengembangan Sistem Informasi, perusahaan perlu merencanakan dan merancang konsep sistem yang benar - benar efektif dan memiliki kualitas yang baik dalam mendukung proses bisnis [13] dan [14].

Pada penelitian ini mengembangkan desain aplikasi android yang dilakukan pada penelitian sebelumnya [9] dengan memanfaatkan konsep industri 4.0. Aplikasi ini mengarah pada kemudahan antara pengunjung dan pemangku Desa (pengelola wisata, UMKM, warga Desa, Kelurahan) untuk lebih bisa mengeksplor dan memberdayagunakan potensi Desa. Aplikasi ini merupakan tools untuk lebih mengenalkan apa yang dimiliki Desa pada pihak luar serta diharapkan dapat memberikan pengalaman baru kepada pengunjung desa untuk mengetahui dari potensi desa yang belum diketahui khalayak umum. Pada penelitian ini memberikan konstribusi dan menutup gap pada penelitian sebelumnya [9] adalah mengkaji perbandingan dua model desain aplikasi yang dievaluasi pada dua desa yang berbeda budaya dan potensi yaitu Desa Ponggok Klaten dan Desa Kadubungbang Pandeglang. Hasil erbandingan dua konsep model pada penelitian selanjutnya sebagai data untuk dasar pembuatan program aplikasi android.

\section{METODOLOGI PENELITIAN}

Bagian ini menjelaskan mengenai tahapantahapan yang akan dilakukan didalam penelitian. Metodologi penelitian ini digunakan sebagai acuan agar penelitian yang dilakukan sesuai dengan framework penelitian.

\subsection{Metode Usulan}

Penelitian ini akan desain model aplikasi android dengan pendekatan antara Quality Fuction Deployment (QFD) untuk mendapatkan bobot antara customer needs dan respon teknis, 
Analytical Hierarchy Process (AHP) berfungsi pada pemilihan prioritas fitur aplikasi yang akan dibuat dan dapat memperoleh alternatif strategis inovatif untuk memperoleh segmen [2], dan System Development Life Cycle (SDLC) untuk merancang desain model sistem yang terdiri dari beberapa fase diantaranya perencanaan, analisis, desain implementasi, dan pemeliharaan [3]. Saat ini, Internet of Things (IOT) banyak digunakan pada beberapa contoh diantaranya, dalam transportasi, kesehatan atau utilitas. Hal yang dihubungkan adalah Thing-to-Human and Human-to-Human yang membentuk jaringan di dalam loT, yang terhubung ke internet. Objek yang dapat diidentifikasi secara individu saling bertukar informasi di dalam jaringan [15], [16], dan [17].

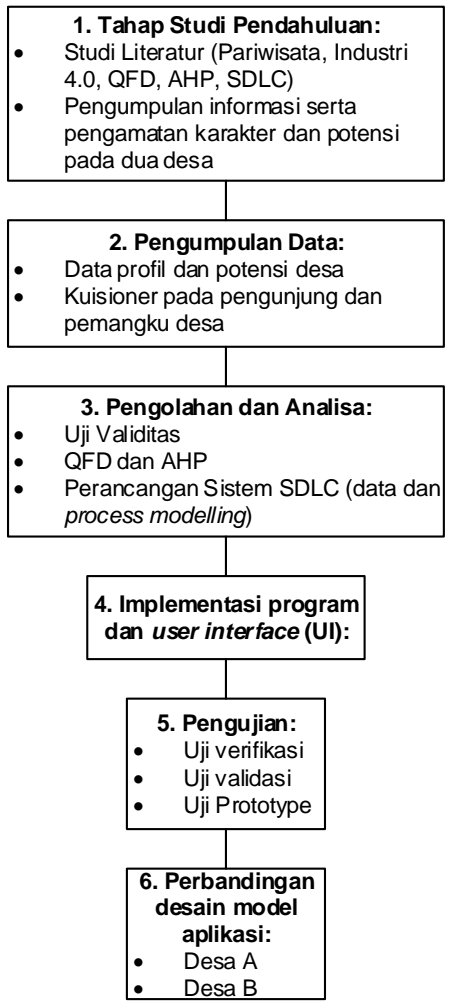

Gambar 1. Flowchart Penelitian

Pada Gambar 1 merupakan alur dari penelitian, pada penelitian ini terdiri dari 6 tahapan dan proses diantaranya: 1. Tahap Studi pendahuluan, 2. Pengumpulan data dilakukan dengan pengambilan data kuisioner untuk input QFD dan AHP serta data profil Desa untuk perbaindingan pada desain model aplikasi, 3. Pengolahan dan analisis data dilakukan dengan uji validitas dan reliabilitas pada data kuisioner pelanggan, data yang sudah valid masuk pada tahap QFD pada customer need serta matrik perbandingan antara customer need dan respon teknis hasil QFD untuk rancangan desain, AHP untuk menentukan tingkat prioritas fitur aplikasi, SDLC tahap process modelling (analisa pieces bisa dilihat pada tabel 10 pada sistem lama, analisa QFD dan AHP, strategi pengembangan model) 4. Implementasi program dan UI tahap implementasi menggunakan bantuan software Marvel App, pembuatan aplikasi ini tidak memerlukan bantuan bahasa pemrograman melainkan hanya dengan cara drag and drop, 5. Pengujian, dan 6. Perbandingan desain aplikasi dua desa. Tahapan itu harus dilakukan karena mempengaruhi dari sistem desain yang terdiri dari input berupa informasi yang luas, dari input masuk tahap proses dan output berupa desain model aplikasi (keandalan dari desain tergantung dari banyaknya sumber informasi yang didapat).

\subsection{Metode pengumpulan data}

Objek dari penelitian ini adalah para pengunjung dari Desa Ponggok (A) serta Kadubungbang (B). Jumlah sampel penelitian akan ditentukan dengan menggunakan perhitungan manual dengan rumus slovin (terdapat pada metode pengumpulan data langkah 2 dan 3). Langkah-langkah dalam pengumpulan data adalah sebagai berikut:

1) Data profil pada 2 Desa (Desa Ponggok dan Desa Kadubungbang) di dapat dari database pada bagian sekretaris desa, berisi tentang: batas desa, topografi, jumlah penduduk, potensi desa, jumlah dan jenis UMKM, sistem pengolahan pemasukan desa (terangkum pada tabel 1).

Tabel 1. Nama dan Potensi Desa

\begin{tabular}{|c|c|c|}
\hline No & Nama Desa & Potensi \\
\hline 1 & $\begin{array}{l}\text { Desa Ponggok, } \\
\text { Klaten-Jawa } \\
\text { Tengah } \\
\text { (Desa A) }\end{array}$ & 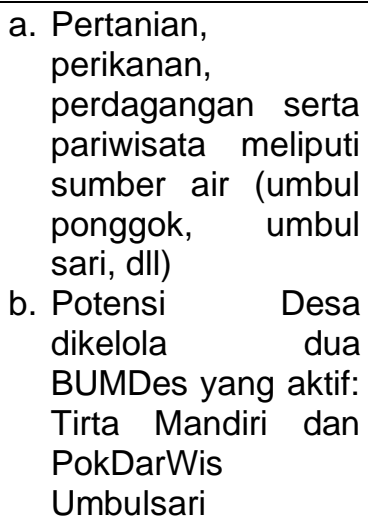 \\
\hline 2 & $\begin{array}{l}\text { Desa } \\
\text { Cikoromoy } \\
\text { Kadubungbang, } \\
\text { Pandeglang- } \\
\text { Jawa Barat } \\
\text { (Desa B) }\end{array}$ & $\begin{array}{l}\text { Pertanian, perikanan } \\
\text { (ikan mas sawah), } \\
\text { perdagangan serta } \\
\text { pariwisata meliputi } \\
\text { sumber air pemandian } \\
\text { (cikoromoy, } \\
\text { abadi), wisata religi } \\
\text { (batu qur'an, cilancar, }\end{array}$ \\
\hline
\end{tabular}




\begin{tabular}{ll}
\hline No Nama Desa & \multicolumn{1}{c}{ Potensi } \\
\hline & cipengantin, dsb, \\
& makam syekh demang \\
& lancar, makam uyut \\
& sarinten) dan tempat \\
& makan terapung yang \\
& unik \\
\hline
\end{tabular}

2) Data kuisioner didapat dari pengunjung (Voice of Customer), masing-masing desa di sebar sejumlah: Desa A 70 (Populasi pengunjung 85 orang dan tingkat kepercayaan $5 \%$ ) dan Desa B 56 (populasi pengunjung 65 orang tingkat kepercayaan $5 \%$ ) (dengan rumus slovin_pada step 3) dan kuisioner AHP didapat dari orang yang berpengalaman (expert) yaitu: Desa A (1 pemangku Desa dan 1 pengelola wisata) dan desa $B$ (1 pemangku Desa).

Tabel 2. Varibel VoC untuk Dua Desa

\begin{tabular}{|c|c|c|}
\hline No & VOC & $\begin{array}{l}\text { Sumber } \\
\text { Referensi }\end{array}$ \\
\hline 1 & $\begin{array}{l}\text { Adanya } \quad \text { informasi } \\
\text { mengenai petunjuk arah } \\
\text { menuju objek wisata } \\
\text { (ADOB) }\end{array}$ & \\
\hline 2 & $\begin{array}{l}\text { Adanya informasi umum } \\
\text { mengenai profil desa } \\
\text { tempat wisata tersebut } \\
\text { (alamat kantor desa, } \\
\text { nomer telpon kantor desa, } \\
\text { kode pos desa, alamat } \\
\text { email desa, potensi } \\
\text { sumber daya alam desa) } \\
\text { (AIW) }\end{array}$ & \\
\hline 3 & $\begin{array}{ll}\text { Adanya informasi } \\
\text { mengenai objek wisata } \\
\text { yang masih belum } \\
\text { terpublis media / belum } \\
\text { terkenal (AIT) }\end{array}$ & $\begin{array}{c}\text { [1], [18], } \\
\text { [11], [7], } \\
\text { Data } \\
\text { Pengamatan }\end{array}$ \\
\hline 4 & $\begin{array}{l}\text { Adanya infromasi } \\
\text { mengenai kegiatan - } \\
\text { kegiatan kedaerahan/ } \\
\text { budaya daerah serta } \\
\text { sejarah desa sebagai } \\
\text { media edukasi (AIE) }\end{array}$ & \\
\hline 5 & $\begin{array}{l}\text { Adanya informasi } \\
\text { mengenai pertanian dan } \\
\text { peternakan yang ada di } \\
\text { desa sebagai media } \\
\text { edukasi (EIEE) }\end{array}$ & \\
\hline 6 & $\begin{array}{lr}\text { Adanya } & \text { informasi } \\
\text { mengenai } & \text { tempat } \\
\text { perbelanjaan oleh }- \text { oleh } \\
\text { khas desa (AIK) }\end{array}$ & \\
\hline
\end{tabular}

\begin{tabular}{cll}
\hline No & \multicolumn{1}{c}{ VoC } & $\begin{array}{c}\text { Sumber } \\
\text { Referensi }\end{array}$ \\
\hline 7 & $\begin{array}{l}\text { Aplikasi mudah digunakan } \\
\text { dan memiliki tampilan } \\
\text { menarik (AIM) }\end{array}$ \\
8 & $\begin{array}{l}\text { Iklan di dalam aplikasi } \\
\text { tidak mengganggu } \\
\text { jalannya aplikasi (AIA) }\end{array}$ \\
\hline
\end{tabular}

Pada Tabel 2 VOC kebutuhan pengunjung Desa A dan Desa B. VOC tersebut akan dijadikan atribut penelitian dalam mendesain aplikasi pada dua Desa. Tabel 3 menunjukan delapan technical responses (sebagai variabel untuk AHP) aplikasi yang diharapkan dapat menjawab kebutuhan pengunjung pada VOC.

Tabel 3. Technical Responses pada Dua Desa

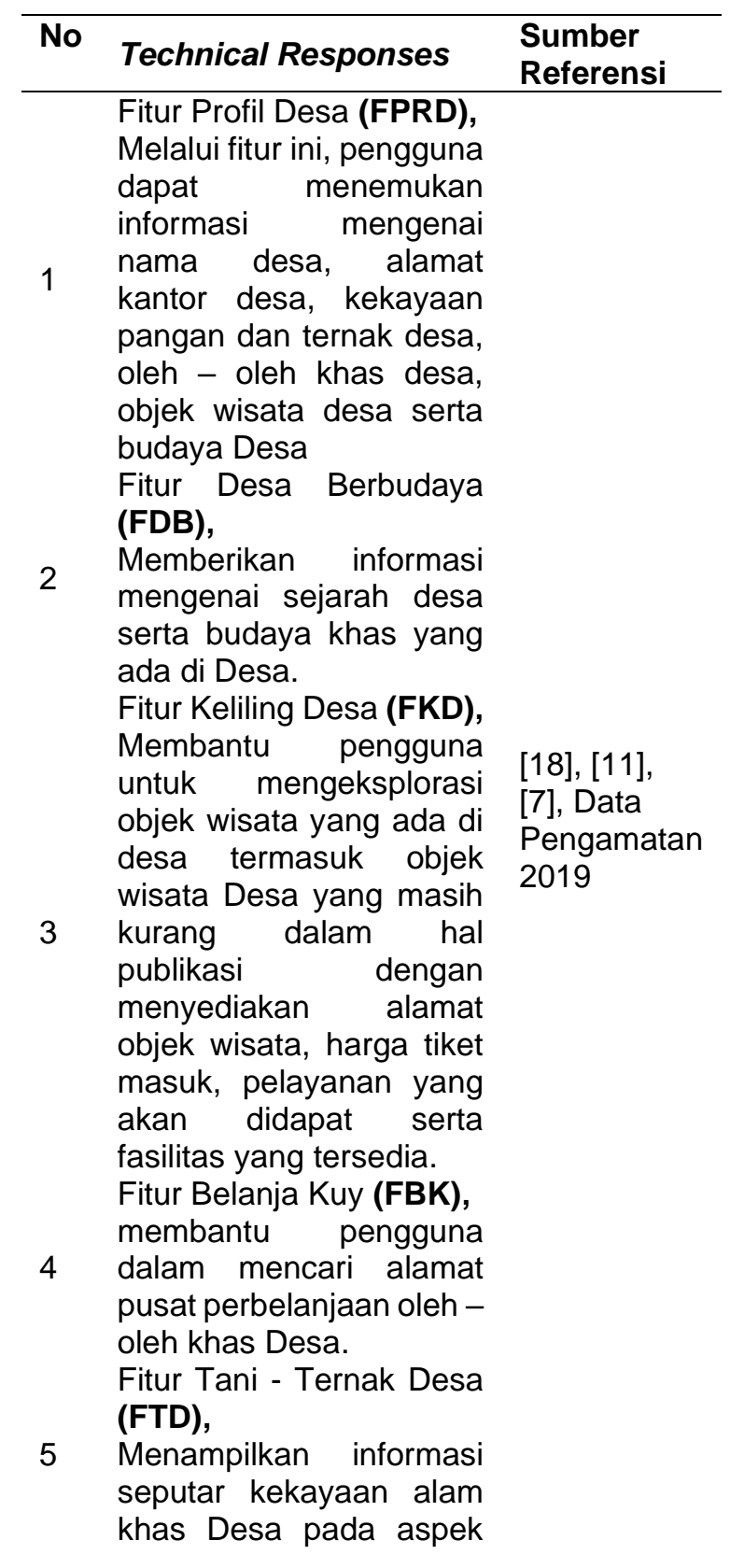




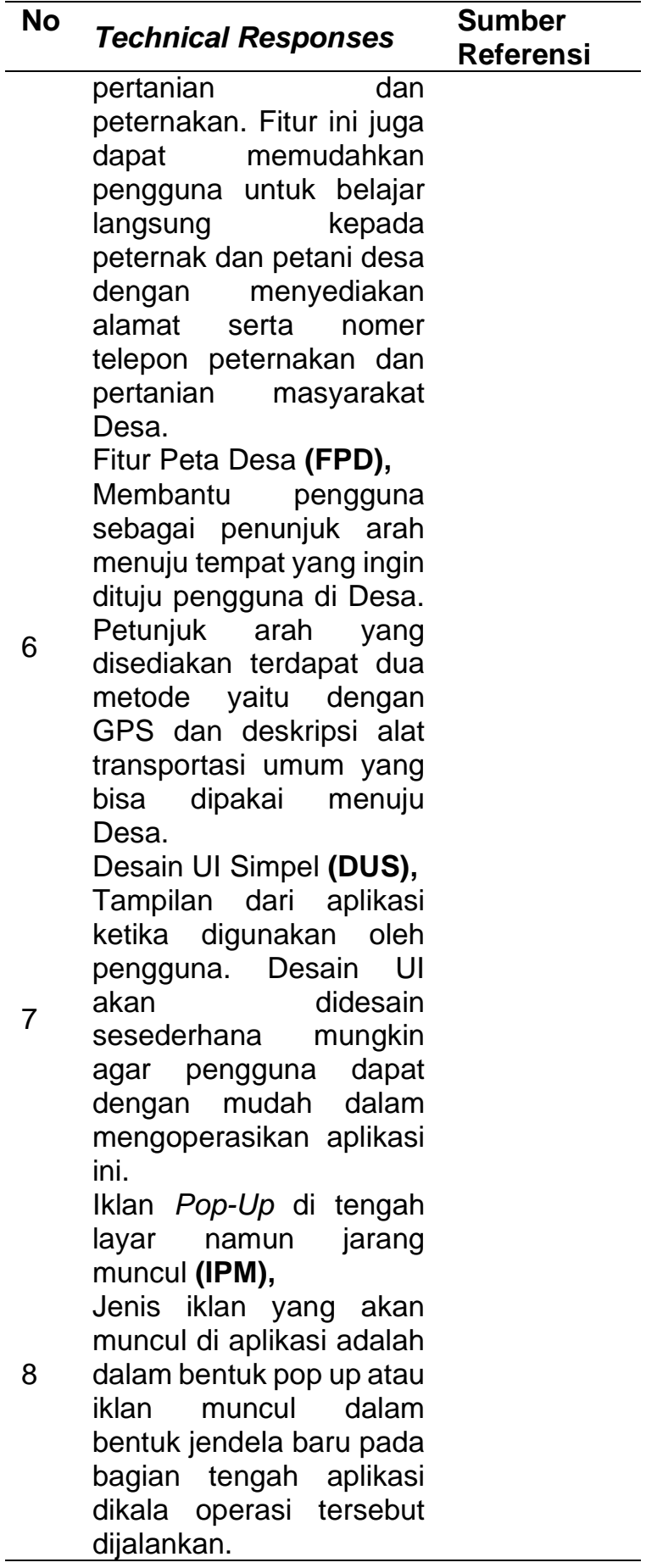

3) Sampel responden yang didapat dari masingmasing Desa menggunakan rumus slovin [10]:

Rumus Slovin $n=\frac{N}{1+N(e)^{2}}$ $\mathrm{e}=$ persen kelonggaran ketidak telitian karena kesalahan pengambilan sampel yang masih dapat ditolerir atau diinginkan, misalnya $5 \%$.

\section{HASIL DAN PEMBAHASAN}

Data untuk VoC yang didapat dari kuisioner pada masing-masing desa diuji validitas dan reliabilitas. Semua hasil menyatakan valid dan reliabel $(R$ tabel pada desa A dan B adalah 0.235) $R$ hitung $\geq$ $\mathrm{R}$ tabel. Variabel dapat digunakan pada proses selanjutnya.

Tabel 4. Importance Rating Desa A dan B

\begin{tabular}{cccc}
\hline $\begin{array}{c}\text { No } \\
\cdot\end{array}$ & Atribut & $\begin{array}{c}\text { Importance } \\
\text { Rating } \\
\text { (Desa A) }\end{array}$ & $\begin{array}{c}\text { Importance } \\
\text { Rating (Desa } \\
\text { B) }\end{array}$ \\
\hline 1 & ADOB & 4.21 & 4,35 \\
\hline 2 & AIW & 4.02 & 3.83 \\
3 & AIT & 4.11 & 4 \\
4 & AIE & 4.02 & 3.9 \\
5 & EIEE & 3.97 & 3.75 \\
6 & AIK & 4.11 & 3.71 \\
7 & AIM & 4.21 & 4.08 \\
8 & AIA & 3.7 & 4.35 \\
\hline
\end{tabular}

Pada Tabel 4 menunjukan bahwa bobot tertinggi yang harus dipenuhi aplikasi adalah adanya informasi mengenai petunjuk arah menuju objek wisata, aplikasi mudah digunakan dan memiliki tampilan menarik, dst sesuai dengan rangking masing-masing variabel. Terdapat kesamaan karena keduanya memiliki wisata andalan sumber mata air.

Tabel 5. HOQ Desa Ponggok (VoC dan Cl)

\begin{tabular}{ccc}
\hline No & VoC & $\begin{array}{c}\text { Customer } \\
\text { Importance }\end{array}$ \\
\hline 1 & ADOB & 4.21 \\
2 & AIW & 4.02 \\
3 & AIT & 4.11 \\
4 & AIE & 4.02 \\
5 & AIEE & 3.97 \\
6 & AIK & 4.11 \\
7 & AIM & 4.21 \\
8 & AIA & 3.7 \\
\multicolumn{4}{c}{ Absolute Important } \\
\end{tabular}

\section{Dimana:}

$\begin{array}{ll}\mathrm{n} & =\text { ukuran sampel } \mathrm{N} \\ \mathrm{N} & =\text { ukura populasi }\end{array}$ 


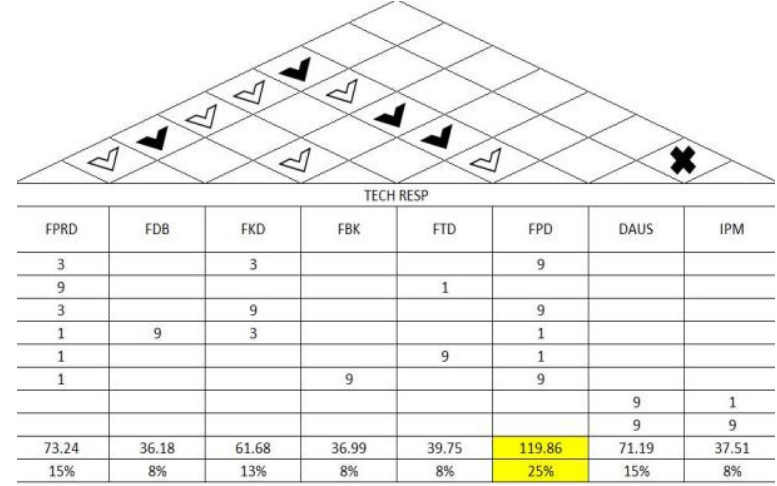

Gambar 2. HOQ Desa Ponggok (Matrik Respon Teknis

Gambar 2 merupakan hasil proses QFD yang dimulai VoC, hubungan VoC dan Respon teknis serta hubungan teknis. Contoh penjelasan pada hubungan teknis pada simbol seperti atap rumah, terdapat hubungan antar respon teknis, contoh: hubungan pada FPRD dengan FDB adalah medium positve, pada hubungan FPRD dengan FKD adalah strong positive, pada hubungan DAUS dengan IPM adalah strong negative, pada hubungan FPD dengan DUS tidak terdapat hubungan/lemah.

Tabel 6. HOQ Desa Kadubungbang (VoC dan $\mathrm{Cl})$

\begin{tabular}{ccc}
\hline No & VoC & Customer Importance \\
\hline 1 & ADOB & 4.35 \\
2 & AIW & 3.38 \\
3 & AIT & 4 \\
4 & AIE & 3.9 \\
5 & AIEE & 3.75 \\
6 & AIK & 4.72 \\
7 & IIM & 4.08 \\
8 & AIA & 3.41 \\
\multicolumn{3}{c}{ Absolute Important } \\
\multicolumn{3}{c}{ Relative Important } \\
\hline
\end{tabular}

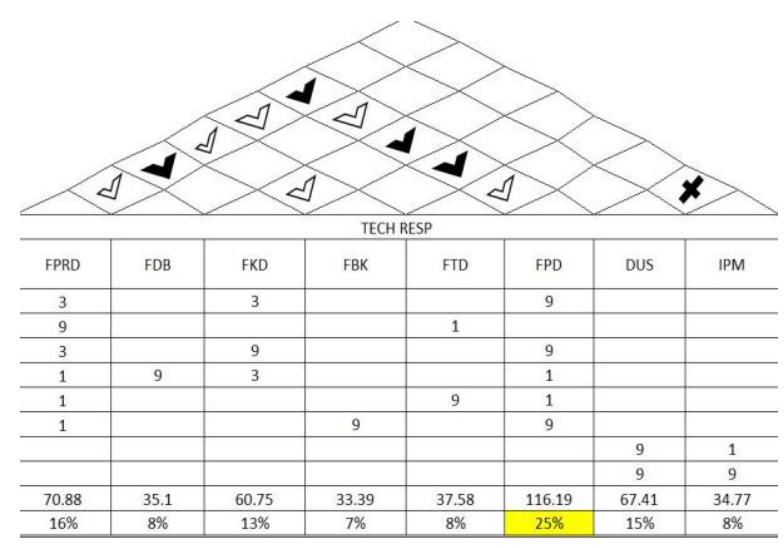

Gambar 3. HOQ Desa Kadubungbang (Matrik Respon Teknis
Hasil QFD di dapat dari data kuisioner dari dua desa, bisa dilihat pada bobot VOC dan bobot Reson Teknis. Gambar 2 dan $\underline{3}$ dan Tabel 5 dan $\underline{6}$ adalah hasil dari proses QFD pada Desa Kadubungbang dan Ponggok, terdapat sedikit perbedaan pada nilai prioritas respon teknis dan nilai voc. Pada bobot respon teknik yaitu samasama pada Fitur Peta Desa (FPD) dengan masing-masing nilai 119.86 dan 116.19. pada bobot VOC yaitu sama-sama pada kebutuhan Adanya informasi mengenai petunjuk arah menuju objek wisata $(A D O B)$ dengan masing-masing nilai 4.21 dan 4.35 , bobot respon teknis bisa dilihat pada masing-masing $\mathrm{HOQ}$.

Tabel 7. Nilai Bobot pada AHP Desa A dan B

\begin{tabular}{cccccc}
\hline No & $\begin{array}{c}\text { Fitur } \\
\text { Aplika } \\
\text { si }\end{array}$ & $\begin{array}{c}\text { Bobot } \\
\text { Desa } \\
\text { (A) }\end{array}$ & $\begin{array}{c}\text { Ran } \\
\text { gkin } \\
\text { g }\end{array}$ & $\begin{array}{c}\text { Bobot } \\
\text { Desa } \\
\text { (B) }\end{array}$ & $\begin{array}{c}\text { Ran } \\
\text { gkin } \\
\text { g }\end{array}$ \\
\hline 1 & FPRD & 0.23 & 1 & 0.15 & 4 \\
2 & FDB & 0.19 & 2 & 0.20 & 1 \\
3 & FKD & 0.13 & 3 & 0.19 & 2 \\
4 & FBK & 0.11 & 4 & 0.11 & 5 \\
5 & FTD & 0.11 & 5 & 0.06 & 6 \\
6 & FPD & 0.09 & 6 & 0.18 & 3 \\
7 & DUS & 0.08 & 7 & 0.06 & 7 \\
8 & IPM & 0.06 & 8 & 0.04 & 8 \\
\hline
\end{tabular}

Pada Tabel 7 merupakan hasil AHP CR masingmasing menunjukkan $\mathrm{CR} \leq 1$, untuk membuat perbandingan, perlu membutuhkan skala angka yang menunjukkan dominan adalah atas elemen lain sehubungan dengan kriteria maka dikatan variabel konsisten. Terkadang dalam suatu penelitian dengan penerapan skala 1-9 terdapat $\mathrm{CR}>0.1$, salah satu untuk $\mathrm{CR} \leq 0.1$ adalah dengan menggunakan 1-5 skala [10], [19] dan [20], maka pada penelitian ini menggunakan skala 1-5. Hasil perhitungan AHP pada dua Desa A dan $B$, terdapat perbedaan pada bobot fitur aplikasi yaitu: Prioritas desa $A \rightarrow$ Fitur Profil Desa (FPRD) 0.23 dan Desa B Fitur Desa Berbudaya (FDB) 0.20 . Hal itu berbeda karena pada Desa B masih memegang pada budaya dan kearifan lokal selanjutnya diutamakan pada pengenalan potensi Desa, dan pada Desa A mengutamakan profil desa karena desa A sudah menjadi Desa mandiri selanjutnya memperkenalkan potensi daerahnya yang masih aktif dikelola BUMDes. Hasil AHP yang didapat digunakan sebagai dasar desain pada fitur aplikasi.

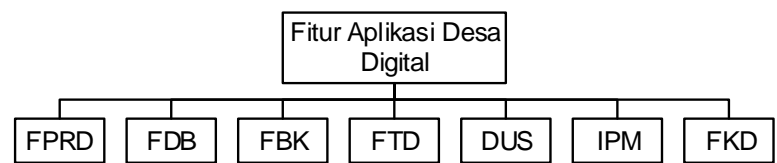

Gambar 4. Kerangka Pemilihan Kriteria AHP Desa A dan B

As'adi , dkk. 
Aplikasi yang akan dirancang berupa aplikasi mobile atau aplikasi yang diakses menggunakan smartphone. Aplikasi ini memiliki 6 fitur diantaranya fitur Keliling Desa, fitur Belanja Kuy, fitur Desa Berbudaya, fitur Peta Desa, fitur Tani Ternak Desa, fitur Profil Desa sebagaimana yang dijelaskan pada tahap Technical Responses QFD dan proses SDLC (Process Modeling). Selain memiliki enam fitur, aplikasi ini memiliki tiga menu utama, yaitu menu Home, menu Maps, dan menu Discover.

Tabel 8. Process Modeling

\begin{tabular}{ll}
\hline Proses & Aturan Proses \\
\hline $\begin{array}{l}\text { Proses } \\
\text { Home }\end{array}$ & $\begin{array}{l}\text { Proses home dapat dilakukan } \\
\text { dengan cara memasukan } \\
\text { data nama desa atau nama } \\
\text { lokasi berdasarkan GPS. }\end{array}$ \\
Proses & $\begin{array}{l}\text { Proses maps dapat dilakukan } \\
\text { dengan cara mengaktifkan }\end{array}$ \\
Maps & $\begin{array}{l}\text { GPS pada smartphone. } \\
\text { Proses }\end{array} \begin{array}{l}\text { Proses discover dapat } \\
\text { dilakukan dengan memilih } \\
\text { objek atsata atau }\end{array}$ \\
\hline
\end{tabular}
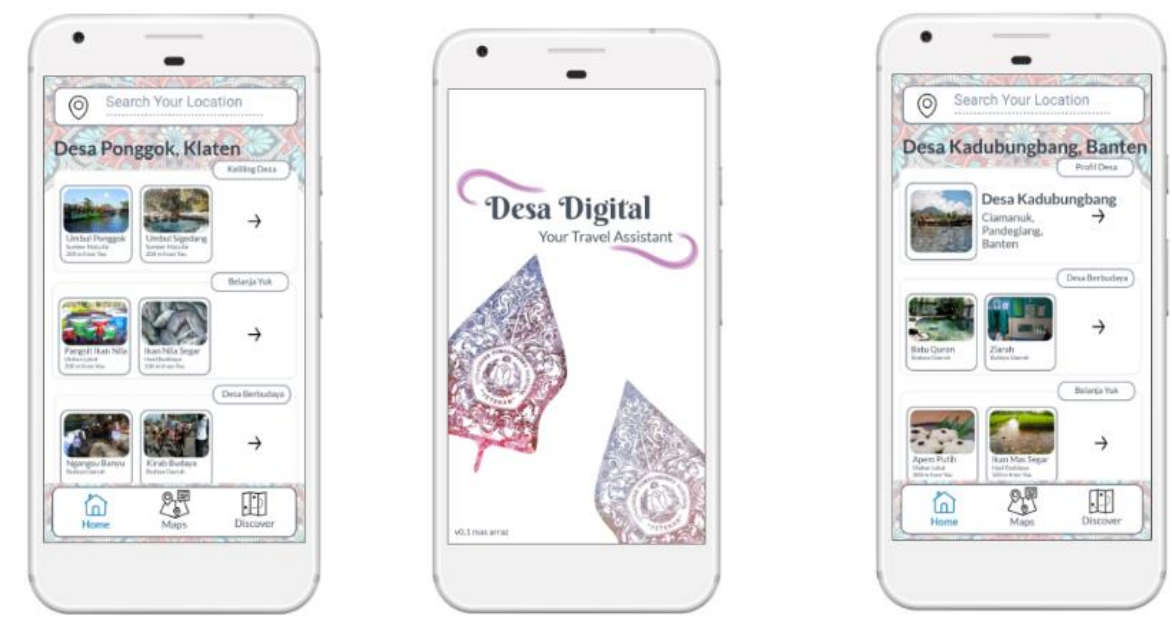

Gambar 5. Tampilan Awal dan Prototype Aplikasi pada Dua Desa

Tabel 9. Perbandingan Analisa PIECES Sistem

\begin{tabular}{ll}
\hline Pembanding & Sistem Lama \\
\hline & 1. Throughput \\
& Sistem hanya berfokus terhadap \\
& proses bisnis masing - masing \\
pengelola wisata, sehingga tidak & terjadi sinergitas yang seharusnya \\
Performance & dapat meningkatkan pemberdayaan \\
industri pariwisata Desa agar lebih \\
optimal.
\end{tabular}

2. Response time

\begin{tabular}{ll}
\hline Proses & Aturan Proses \\
\hline & $\begin{array}{l}\text { memasukan nama objek } \\
\text { wisata yang ingin dicari. }\end{array}$ \\
\hline
\end{tabular}

Gambar 5 merupakan tampilan awal desain aplikasi selain itu tahap pengujian belum dapat dilakukan secara optimal. Hal itu dikarenakan pada keterbatasan software yang dipakai serta ranah Penelitian Program Studi Teknik Industri pada tahap implementasi, yaitu prototype yang dihasilkan masih dalam berupa desain visualisasi aplikasi yang mana masih membutuhkan pengembangan lebih lanjut pada implementasi database dan algoritma dalam bahasa pemrograman sehingga aplikasi dapat berjalan sesuai dengan fungsinya dan dapat digunakan secara langsung oleh pengunjung. Dari fitur yang terapkan pada desain dibuat berdarkan hasil dari AHP pada masing-masing dua Desa.

\section{Sistem Baru}

1. Throughput

Sinergisitas antara Pengelola wisata Desa dan wisatawan dalam satu sistem. Proses bisnis yang ada bukan hanya meliputi aspek ekonomis namun dengan adanya sistem aplikasi Desa Digital yang lebih atraktif dan menarik ini diharapkan dapat menigkatkan aspek kepuasan wisatawan yang berkunjung ke Desa.

2. Response time 


\begin{tabular}{ll}
\hline Pembanding & Sistem Lama \\
\hline & Waktu yang dibutuhkan bagi \\
wisatawan untuk mencari tahu \\
informasi objek wisata Desa lebih \\
lama karena harus bertanya dengan \\
warga setempat. \\
3. Output \\
Masih kurangnya informasi aktual \\
mengenai harga tiket masuk serta \\
kurangnya informasi mengenai objek \\
wisata yang masih belum terkenal \\
namun memiliki potensi. \\
4. Input \\
Kurangnya informasi yang dipublikasi \\
mengenai objek wisata terutama \\
objek wisata yang dikelola oleh \\
BUMDes. \\
5. Storage \\
Penyimpanan data yang tidak \\
diperbarui terhadap informasi yang \\
aktual serta data objek wisata belum \\
terorganisir dengan baik sehingga \\
masih terjadi kekurangan informasi \\
yang dialami oleh wisatawan. \\
6. Cost \\
Biaya yang dihabiskan lebih banyak \\
karena masih ada beberapa strategi \\
pemasaran yang kurang efektif.
\end{tabular}

Economy

7. Profit

Profit yang dihasilkan seharusnya masih bisa lebih optimal lagi.

Pengontrolan sulit dilakukan karena Control terbatasnya kemampuan SDM dalam mengelola website.

Diperlukannya upaya yang lebih jika

Efficiency ingin mencari tahu objek wisata yang ada di Desa.

Sistem yang ada sekarang tidak memberikan hasil yang relavan

Services

\section{Sistem Baru}

Waktu yang dibutuhkan bagi wisatawan untuk mencari tahu informasi objek wisata Desa Ponggok lebih cepat karena terhubung langsung dengan server Aplikasi Desa Digital.

\section{Output}

Informasi yang didapat oleh wisatawan lebih akurat, aktual, dan lebih luas mengenai informasi objek wisata Desa dengan segala sumber daya potensial desa yang menarik lainnya.

\section{Input}

Informasi yang ada di dalam database aplikasi Desa Digital lebih mudah karena pengelolaan sistem aplikasi diatur oleh satu administrator.

5. Storage

Penyimpanan data pada server Aplikasi Desa Digital selalu diperbarui, lebih terorganisir serta lebih aman karena pengelolaan informasi pada sistem aplikasi hanya diatur oleh administrator.

\section{Cost}

Biaya yang dihabiskan dapat lebih kecil dibandingkan menggunakan sistem yang lama karena sistem baru bekerja lebih efektif dan efisien dalam hal pengelolaan dan hubungan dengan wisatawan.

7. Profit

Profit yang dihasilkan dapat lebih optimal karena biaya yang dikeluarkan oleh pengelola objek wisata desa dapat diminimalkan serta kegiatan publikasi lebih efektif dan lebih atraktif.

Pengontrolan lebih mudah dilakukan karena pengelolaan informasi pada sistem aplikasi hanya diatur oleh administrator.

Sistem baru dinilai lebih efisien karena kinerja yang diberikan lebih efektif dibandingkan dengan sistem lama.

Sistem aplikasi Desa Digital dapat memberikan hasil yang akurat, aktual, serta memberikan nilai tambah kepuasan terhadap wisatawan yang datang ke Desa. serta informasi yang disediakan tidak aktual.

Pada penelitian ini terdapat kontribusi dari sisi perbandingan variabel pengunjung dan fitur aplikasi yang di evaluasi pada dua desa yang berbeda. 
Tabel 10. Perbandingan Variabel Dua Desa

\begin{tabular}{|c|c|c|c|}
\hline No & Desa & $\begin{array}{c}\text { Perb } \\
\text { andin } \\
\text { aan }\end{array}$ & $\begin{array}{c}\text { Variabel } \\
\text { Perbandingan }\end{array}$ \\
\hline \multirow{3}{*}{1} & \multirow{3}{*}{ Ponggok } & $\begin{array}{l}\text { Studi } \\
\text { Pend } \\
\text { ahulu } \\
\text { an }\end{array}$ & $\begin{array}{lr}\text { Memiliki } & \text { potensi } \\
\text { sumber mata air } \\
\text { dan pertanian, } \\
\text { rata-rata dikelola } \\
\text { BUMDes } \\
\text { masih aktif }\end{array}$ \\
\hline & & $\begin{array}{l}\text { Priorit } \\
\text { as } \\
\text { Peng } \\
\text { unjun } \\
\mathrm{g}\end{array}$ & $\begin{array}{l}\text { Adanya informasi } \\
\text { mengenai petunjuk } \\
\text { arah menuju objek } \\
\text { wisata, dan } \\
\text { selanjutnya bisa } \\
\text { dilihat pada tabel } 5\end{array}$ \\
\hline & & $\begin{array}{l}\text { Priorit } \\
\text { as } \\
\text { Fitur } \\
\text { Aplika } \\
\text { si }\end{array}$ & $\begin{array}{l}\text { Fitur profil Desa, } \\
\text { selanjutnya bisa } \\
\text { dilihat pada tabel } 4\end{array}$ \\
\hline \multirow{3}{*}{2} & \multirow{3}{*}{$\begin{array}{c}\text { Kadubung } \\
\text { bang }\end{array}$} & $\begin{array}{l}\text { Studi } \\
\text { Pend } \\
\text { ahulu } \\
\text { an }\end{array}$ & $\begin{array}{l}\text { Memiliki potensi } \\
\text { sumber mata air, } \\
\text { perikanan, dan } \\
\text { wisata religi }\end{array}$ \\
\hline & & $\begin{array}{l}\text { Priorit } \\
\text { as } \\
\text { Peng } \\
\text { unjun } \\
\mathrm{g}\end{array}$ & $\begin{array}{l}\text { Adanya informasi } \\
\text { mengenai petunjuk } \\
\text { arah menuju objek } \\
\text { wisata, dan } \\
\text { selanjutnya bisa } \\
\text { dilihat pada tabel } 6\end{array}$ \\
\hline & & $\begin{array}{l}\text { Priorit } \\
\text { as } \\
\text { Fitur } \\
\text { Aplika } \\
\text { si }\end{array}$ & $\begin{array}{l}\text { Fitur Desa Budaya, } \\
\text { selanjutnya bisa } \\
\text { dilihat pada tabel } 4\end{array}$ \\
\hline
\end{tabular}

Pada Tabel 10 merupakan hasil perbandingan dari proses QFD dan AHP pada Desa Ponggok dan Desa Kadubungbang. Desain aplikasi memiliki perbedaan hanya pada rioritas fitur, tetapi secara teknis desain aplikasi berkarakter fleksibel dan dapat diterapkan pada desa yang berbeda. Dilihat pada studi pendahuluan keduanya sama-sama memiliki potensi sumber mata air dan pada Desa Ponggok memiliki potensi pertanian pada Desa Kadubungbang memiliki potensi perikanan (ikan mas sawah) serta wisata religi. Rata-rata pada prioritas pengunjung memiliki kesamaan yaitu adanya informasi yang jelas mengenai arah ke tempat wisata, hal ini penting karena pengunjung bisa mengekspos dan mengetahui potendi Desa yang bisa memberikan pengalaman yang menyenangkan dan bisa terpublikasi di luar daerah. Pada fitur prioritas memiliki perbedaan yaitu: Desa Ponggok mengutamakan profil desa dan Desa Kadubungbang mengutamakan fitur Desa berbudaya, hal ini berbeda karena daerah Desa Ponggok sudah memiliki program Desa mandiri dan seluruh wisata sumber mata air dikelola BUMDes yang masih aktif, sedang Desa Kadubungbang masih kental dengan kearifan budaya lokal.

\section{KESIMPULAN}

Penelitian ini aplikasi bersifat fleksibel karena bisa diterapkan pada desa yang berbeda karakter berdasarkan hasil studi lapangan dan proses analisa, didapatkan bahwa dengan metode QFD dan AHP dapat diketahui prioritas kebutuhan pengunjung dan prioritas fitur aplikasi. Dari perbandingan pada obyek yang berbeda memiliki kesaman dan perbedaan, pada kesamaan terdapat pada kebutuhan pengunjung yang ratarata pengunjung bertujuan berwisata dimana tempat wisata memiliki keunikan tersendiri hal itu yang menjadi daya tarik pengunjung. Pada perbedaan terdapat pada priorotas fitur aplikasi, hal ini karena kedua desa memiliki letak geografis serta budaya yang berbeda dan memiliki program desa yang berbeda. Analisa data pengunjung dan prioritas aplikasi dapat digunakan dasar untuk membuat desain model aplikasi pada penelitian berikutnya.

Saran pada penelitian ini, masih banyak peluang pada metode untuk bisa mengembangkan dari kebutuhan pengunjung dan prioritas fitur dan strategi bisnis model, informasi tentang desa lebih diperluas dan diperkaya untuk data pendukung pembuatan aplikasi android. Implementasi pada perbandingan berpeluang untuk diterapkan pada berbagai Desa. Pihak Pemangku Desa lebih bisa bersinergi dengan warga, pengelola tempat wisata, pengunjung, pihak swasta, sekolah, kampus, dan pemerintah untuk tercipta kemitraan yang berkelanjutan.

\section{DAFTAR PUSTAKA}

[1] V. Alcácer and V. Cruz-Machado, "Scanning the Industry 4.0: A Literature Review on Technologies for Manufacturing Systems," Eng. Sci. Technol. an Int. J., vol. 22, no. 3, pp. 899-919, 2019, doi: 10.1016/j.jestch.2019.01.006.

[2] H. Prasetyo and W. Sutopo, "Perkembangan Keilmuan Teknik Industri 
Menuju Era," in Seminar dan Konferensi Nasional IDEC 2017, 2017, pp. 488-496.

[3] B. Prasetyo and D. Trisyanti, "Prosiding Semateksos 3 'Strategi Pembangunan Nasional MenghadapiRevolusilndustri 4.0' REVOLUSI INDUSTRI 4.0," Revolusi Ind. 4.0 dan Tantangan Perubahan Sos., pp. 22-27, 2019.

[4] Kementerian pariwisata RI, "Rencana Strategis 2018-2019 Kementerian Pariwisata,"

Www.Kemenpar.Go.ld/Post/RencanaStrategis-2018-2019-KementerianPariwisata, 2018, 10.1017/CBO9781107415324.004.

[5] "Home - Berdesa." [diakses pada tanggal 29 agustus 2019].

[6] F. Pauker, T. Frühwirth, B. Kittl, and W. Kastner, "A Systematic Approach to OPC UA Information Model Design," Procedia CIRP, vol. 57, pp. 321-326, 2016, doi: 10.1016/j.procir.2016.11.056.

[7] E. Serova, "Enterprise information systems of new generation," 4th Int. Conf. Inf. Warf. Secur. ICIW 2009, vol. 15, no. 1, pp. 452 457, 2009.

[8] F.-È. Bordeleau, E. Mosconi, and L. A. Santa-Eulalia, "Business Intelligence in Industry 4.0: State of the art and research opportunities," Proc. 51st Hawaii Int. Conf. Syst. Sci., no. January, pp. 0-10, 2018, doi: 10.24251/hicss.2018.495.

[9] A. N. Viacenza, "Pengembangan Industri Pariwisata Berbasis Aplikasi Mobile Dengan Metode System Development Life Cycle Dan Quality Function Deployment," Universitas Pembangunan Nasional "veteran" Jakarta, 2019.

[10] A. N. Zaman, "Kajian Implementasi Metodologi Desain Product Service System (Pss) Dengan Qfd Multi Layer Di Perusahaan Karoseri," Institut Teknologi Sepuluh Nopember, 2016.

[11] S. A. Schenkl, C. Rösch, and M. Mörtl, "Literature study on factors influencing the market acceptance of PSS," Procedia CIRP, vol. 16, pp. 98-103, 2014, doi: 10.1016/j.procir.2014.01.013.
Hadiguna, "Antara Desain Dan ProductService Systems: Suatu Tinjauan Literatur," J. Optimasi Sist. Ind., vol. 12, no. 1 p. $335, \quad 2016$, doi: 10.25077/josi.v12.n1.p335-342.2013.

[13] Taufik Asharryan Triadi, "No Title," in Design For Six Sigma Pada Pengembangan Konseptual Sistem Informasi Terintegrasi Studi Kasus Pada Toko X Grosir Dan Eceran Cianjur, 2018.

[14] L. Pane et al., "Upaya Peningkatan Kualitas Jasa Kesehatan Menggunakan Integrasi Quality Function Deployment (Qfd) Dengan Analytical Hierarchy Process (Ahp)," J. Tek. Ind. USU, vol. 1, no. 3, pp. 31-36, 2013.

[15] K. Choi and S. H. Chung, "Enhanced timeslotted channel hopping scheduling with quick setup time for industrial Internet of Things networks," Int. J. Distrib. Sens. Networks, vol. 13, no. 6, pp. 1-14, 2017, doi: $10.1177 / 1550147717713629$.

[16] M. N. O. Sadiku, Y. Wang, S. Cui, S. M. Musa, and R. G. Perry, "International Journal of Advances in Scientific Research and Engineering (ijasre) Industrial Internet Of Things," vol. 3, no. 11, pp. 1-5, 2017, doi: 10.7324/IJASRE.2017.32538.

[17] O. B. Sezer, E. Dogdu, and A. M. Ozbayoglu, "Context-Aware Computing, Learning, and Big Data in Internet of Things: A Survey," IEEE Internet Things J., vol. 5, no. 1, pp. 1-27, 2018, doi: 10.1109/JIOT.2017.2773600.

[18] H. Prasetyo and W. Sutopo, "INDUSTRI 4.0: Telaah Klasifikasi Aspek Dan Arah Perkembangan Riset," J@ti Undip J.Tek. Ind., vol. 13, no. 1, p. 17, Mar. 2018, doi: 10.14710/jati.13.1.17-26.

[19] G. P. White, "The implementation of management science in higher education administration," Omega, vol. 15, no. 4, pp. 283-290, 1987, doi: 10.1016/03050483(87)90016-8.

[20] M. F. Hossain, Z. H. Adnan, and M. A. A. Hasin, "Improvement in weighting assignment process in analytic hierarchy process by introducing suggestion matrix and Likert scale," Int. J. Supply Chain Manag., vol. 3, no. 4, pp. 91-95, 2014.

B. Yuliandra, A. Sutanto, and R. A. 


\section{Biografi Penulis}

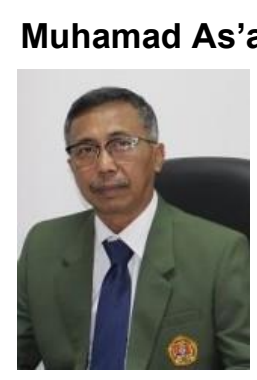

Bidang keilmuan penulis adalah Mesin dan Manajemen Proyek. Penulis aktif mengajar di Teknik Industri UPNVJ dengan bidang yang diajar: Teknik Keandalan dan Manajemen Proyek. Penulis sangat antusias dan aktif pada kegiatan sosial kebangsaan.

\section{Akhmad Nidhomuz Zaman (2)}

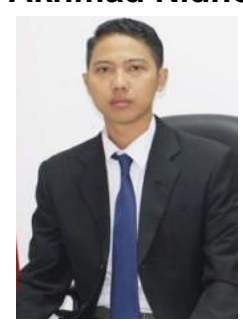

Bidang keilmuaan penulis adalah Teknik Industri Manufaktur dan sustainability. Hal-hal yang mengenai ruang riset teknik kearah sosial dan lingkungan sangat disukai penulis. Sejarah negeri nusantara atau jawi sangat disukai penulis.

\section{Alina Cynthia Dewi $i^{(3)}$}

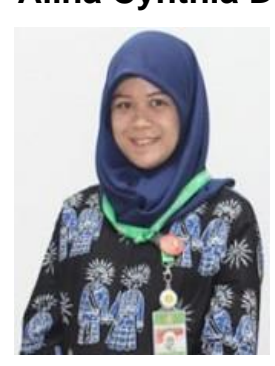

Bidang keilmuhan penulis adalah Manajemen Industri dan alumni ITB. Penulis aktif mengajar di Teknik Industri UPNVJ dengan Mata Kuliah yang diajar: Statistik, Matematika Optimasi, dan kalkulus. Beberapa paper dan jurnal yang dihasilkan pada ruang lingkup Manajemen Kinerja dan Statistik.

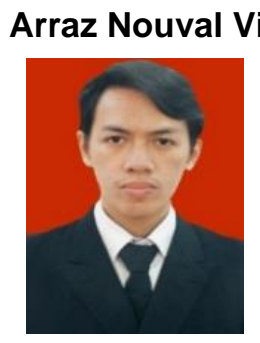

acenza $^{(4)}$

Penulis yang satu ini pernah menjabat sebagai ketua ECORO (kelompok mahasiswa untuk kepentingan lingkungan) UPNVJ satu periode. Alumni UPNVJ 2019 sekarang bekerja pada perusahaan pada departemen pengembangan produk.

\section{Donny Montreano(5)}

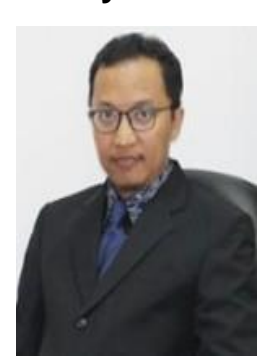

Bidang keilmuhan penulis adalah Manufaktur dan CIM merupakan alumni Universitas Trisakti. Penulis aktif mengajar di Teknik Industri UPNVJ dengan Mata Kuliah yang diajar: Pemrograman Komputer, Simulasi Sistem, Gambar Teknik, dan Optimasi 